\title{
The Impact of Social Accountability Mechanisms on Fiscal Management Challenges Facing Goromonzi Rural District Council, Zimbabwe
}

\author{
Trust Madhovi (Corresponding Author) \\ College of Peace, Leadership and Governance \\ Africa University, Zimbabwe \\ E-mail: madhovit@gmail.com
}

Received: April 12, 2020 Accepted: May 12, 2020 Online published: May 25, 2020

doi:10.5296/jpag.v10i2.16825 URL: https://doi.org/10.5296/jpag.v10i2.16825

\begin{abstract}
This paper examines the impact of social accountability mechanisms on the fiscal management challenges facing local government bodies in Zimbabwe. The paper hypothesises that there is a positive relationship between the use of social accountability mechanisms or tools by local authorities and the effectiveness of their fiscal management policies to mobilize more revenue for service delivery. In this study, both quantitative and qualitative methods are adopted in gathering and analysing data from central government officials, Goromonzi Rural District Council employees and members of the public. The results of the study reveal that the local government body faces a number of fiscal management challenges that include a shrinking tax base, non-payment of taxes, resistance to successive budgets; lack of implementation; lack of monitoring and evaluation. Council has implemented participatory budgeting to deal with some of these challenges. While results show a significant improvement in tax collection, some of the challenges have persisted. The paper proposes some recommendations useful to central government, policy makers, civil society organisations, local government officials and the general public. The paper manages to demonstrate that the implementation of social accountability tools can have positive impacts on the fiscal management challenges facing local governments.
\end{abstract}

Keywords: accountability, social accountability, local authority, long route, short route, participatory budgeting, information dissemination, expenditure tracking 


\section{Introduction}

For the past two decades, social accountability mechanisms have been implemented to address the fiscal management challenges facing local government bodies throughout the globe. In Sub Saharan Africa, the use of social accountability mechanisms has not been prevalent until the mid-2000s and was mainly championed by international development agencies and civil society organisations. In Zimbabwe, social accountability programmes have mainly taken a human rights approach aimed at raising citizen awareness on their right to be involved in local decision making and demand accountability from those in positions of authority. This coupled with the enactment of the new Constitution in 2013 has culminated in a more informed and highly demanding citizenry. According to Muchadenyika (2017), there are 32 urban and 60 rural local authorities in Zimbabwe. Local authorities have generally been accused of short changing the very same citizenry that they are supposed to serve with citizens expressing dissatisfaction with the quantum and quality of public services. Consequently, sequential local authorities budgets have been resisted thus throwing them into serious fiscal management challenges.

Goromonzi Rural District Council is one of the 60 rural district councils in the country. It derives its mandate from the Rural District Councils Act [Chapter 29:13] and a number of other statutes (Munyede \& Mapuva, 2020). It is located in Mashonaland East Province and shares its boundaries with the capital city, Harare to the West. The local authority also shares its boundaries with the following rural district councils: Manyame to the South, Murehwa to the North East, Mazowe and Shamva to the North West; Bindura to the North, and Marondera to the East. It has a population of 224987 largely cosmopolitan inhabitants and covers an area of 9100 square kilometres in extent (ZIMSTAT, 2012). The local authority has also not been spared by the fiscal management challenges facing other local authorities with reports indicating that its debtor's figure has ballooned to unprecedented levels due to poor revenue collection and resistance to successive budgets. As a consequence, it has been failing to honour some of its critical financial obligations with some projects going for a number of years without being completed. Public services such as education and health; waste management; water and sanitation; planning; housing and road maintenance have severely been impacted amid serious allegations of elite capture; misallocation of resources; fiscal haemorrhaging; clientelism and the general lack of transparency and accountability in fiscal management. The local authority's fiscal management position has been aggravated by the rapid and chaotic urbanisation amid reverse migration from the nearby urban local authorities. This situation has resulted in an upsurge in the demand for public services which has further put a strain on its meagre financial resources as the deficit between availability of financial resources and its spending needs increases. Additionally, the local authority has been negatively impacted by the dwindling revenue base caused by the prevailing economic challenges and the recentralisation of viable sources of revenue. It is thus increasingly reliant on governmental transfers to finance its capital projects. These challenges coupled with a number of unfunded mandates have seriously affected the local authority's fiscal management position.

Goromonzi Rural District Council has implemented a number of interventions to improve its fiscal management position. One such intervention has been the application of various social 
accountability mechanisms in its budgeting processes. Despite the increasing prominence and debate on the subject, studies on the impact of social accountability mechanisms on the fiscal management challenges facing local authorities in Zimbabwe have been scanty. Previous studies have mainly focused on how civil society organisations have employed social accountability mechanisms to amplify citizen voice and demand accountability from central and local governments. Thus the current study was intended to bridge this gap.

The main aim of this study was to investigate the impact of social accountability mechanisms on the fiscal management challenges facing Goromonzi Rural District Council. The study hypothesised that the use of appropriate social accountability tools has a positive impact on the fiscal management challenges facing local authorities by fostering dialogue and enhancing the relationship between citizens and power holders. By employing mixed methods to gather and analyse data, the study sought to provide answers to the following pertinent questions:

- What are the views of the citizens on the local authority's budget setting?

- What is the degree of citizen involvement in the local authority's budget monitoring and evaluation?

- How often do citizens attend Goromonzi Rural District Council's budget consultation meetings?

- What is the level of citizen satisfaction with the local authority's budgeting process?

- How have successive budgets for the local authority performed?

The fiscal management challenges facing local authorities have reached alarming levels in Zimbabwe and need to be urgently addressed to save them from imminent collapse. Central government; local authorities; civil society organisations and other stakeholders have previously embraced social accountability interventions but with limited success. This study was intended to enlighten the above stakeholders in remodelling their social accountability initiatives to have a positive impact on livelihoods. In addition, other researchers and the academia would gain valuable insights on social accountability and the fiscal management challenges afflicting local authorities. Members of the public would benefit by appreciating their rights to be involved in local decision making including the obligations of power holders.

\section{Defining Concepts and Theoretical Framework}

\subsection{The Concept of Accountability}

According to Shah (2007) accountability refers to the obligation of power holders to account for or take responsibility for their actions in both their conduct and behaviour. Newell \& Bellour (2002) add that accountability clarifies the rights and responsibilities between the citizens and the institutions that affect their livelihoods specifically the obligations of the state towards the rights of the people. Thus, accountability denotes a social contract between those governing the affairs of the state and the citizens. In this kind of relationship, the state has to be responsive to the needs of the citizens and be accountable for its actions while the 
citizens on their part have to be responsible and play an active role in state building. The available body of literature interprets accountability as the transparency of information or an explanation and ability to answer for one's actions (Barberis, 1998). The dissemination of timeous and accurate information by the state to its citizens is thus one of the key pillars of accountability. According to Hopwood \& Thomkins (1984), there are a number of dimensions to accountability which include legal probity, financial, managerial, programme and policy accountability. Malena, Forster \& Singh (2004) define power holders as those who hold political, financial or other forms of power and include officials in government, private corporations, international institutions and civil society organisations. All the above actors provide a certain type of service to the people and thus should explain their actions to their consumers.

\subsection{The Concept of Social Accountability}

Agarwal, Heltberg \& Diachok (2009) define social accountability as an approach of building accountability that depends on civic engagement where ordinary members of the public or civic society bodies participate directly or indirectly to demand for accountability from public officials or bodies. It is a specific approach or set of tools to exacting accountability and includes state or citizen initiatives or both and is usually demand driven from the grassroots. Houtzager \& Joshi (2008) weigh in by defining social accountability as a form of civic engagement that builds accountability through the collective efforts of citizens and civil society organisations to hold public officials, service providers and governments to account for their obligations with responsive efforts. This definition concurs with that proffered by Kohli (2012) who defines social accountability as the various actions, tools, and mechanisms that can be used by civil society organisations, the media, citizens and communities to hold elected public officials and non-elected public servants accountable. The UNDP (2013) further defines social accountability as the extent and capacity of citizens to hold the state and service providers accountable and make them responsive to the needs of the citizens and beneficiaries. Malena, Forster \& Singh (2004) argue that participation in policy making; policy advocacy and deliberation are part and parcel of social accountability.

There are two methods to social accountability which are the long route and short route (World Bank, 2003). The long route takes a top down approach to accountability and is the method used by central government to monitor the activities of public agencies. It relies on external control and encompasses rules and regulations; bringing in market principles to government agencies; independent agencies such as the office of the ombudsman, parliamentary committees, vigilant commissions, judiciary, and auditor general's office. According to Ringold, Holla, Koziol, Srinivasan \& Santhosh (2012), in the long route method citizens influence policy makers who in turn influence service delivery through providers. The long route is usually hierarchical and bureaucratic in nature with feedback often taking too long.

On the other hand, the short route to public accountability takes a bottom up approach and involves ordinary people and civil society organisations. There is direct communication between the grassroots and the public entities or officials thereby ensuring that responses are 
received on time. The ordinary citizens and civil society are empowered to demand direct accountability from public officials and bodies. For the short route to be effective, citizens need to have unhindered access to accurate information. Figure 1 shows the relationships between public entities and citizens.

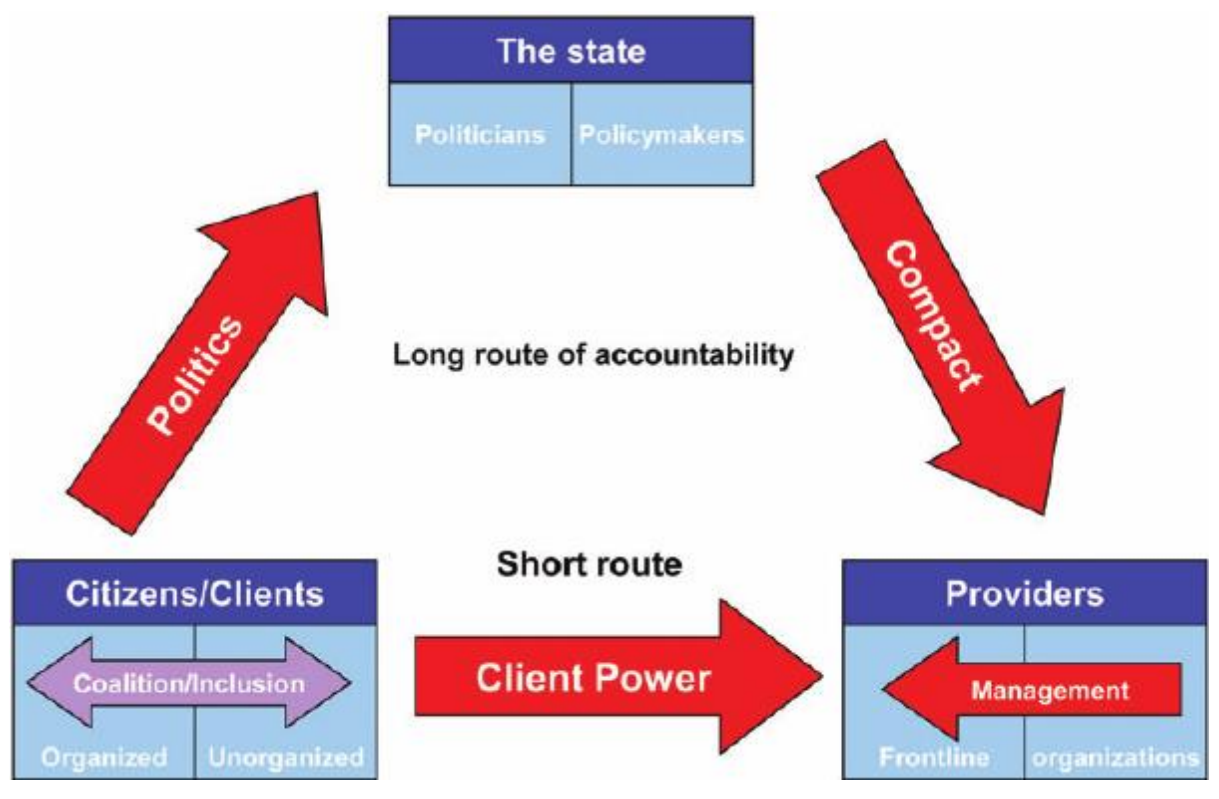

Figure 1. The Accountability Triangle

Source: World Bank (2003)

However, the short route and long route methods should not be applied in isolation as both are intertwined and complementary in demanding public accountability (Devarajan, Khemani $\&$ Walton, 2014). They argue that long route studies tend to diminish the important role played by the citizens and civil society in demanding greater accountability from public entities and officials. Furthermore, they argue that the short route also tends to overlook the role of independent central government bodies charged with bringing public entities and officials to account.

\subsection{Definition of Fiscal Management}

Fiscal management revolves around how governments plan, raise and expend their revenues in the provision of public goods and services. According to Nigro \& Nigro (1988) fiscal management refers to the planning, directing, controlling, organising, coordinating, monitoring and supervising the revenue and spending activities of government. It can be deduced from the above definition that fiscal management is concerned with the administration of all government finances in the delivery of public goods and services. Visser \& Erasmus (2002) define financial management as encompassing the institutions, systems, procedures and the instruments through which governments collect revenue, expend money and exercise control through the budget. Thus fiscal management is concerned with how public finances are administered by those entrusted to hold public offices. 


\subsection{Social Accountability and Fiscal Management}

The manner in which public finances are administered should not be masked in secrecy but should be in the glare of the citizens' eyes. Local authorities are expected to fulfil the diverse expectations of the public by executing consecutive budgets as intended while preventing leakages. It is incumbent upon local authorities to ensure that the limited resources at their disposal are utilised effectively, efficiently and with economy for the benefit of the citizens. Empirical evidence suggests that good fiscal management policies and practices promote the delivery of high quality public goods and services by local authorities. Social accountability can improve fiscal management through the promotion of active citizen participation in local decision making and inculcating a culture of accountability among public officials. It can result in the plugging of leakages, setting of better priorities and effective monitoring and evaluation thus leading to better service delivery outcomes. Social accountability enables citizens to better appreciate fiscal constraints and how local authorities raise revenue, plan and execute fiscal policies to enhance service delivery. In this way, citizens can contribute towards lasting solutions to fiscal management challenges. Moreover, it can enhance the fiscal management position of local authorities through inclusive fiscal decision making which promotes local democracy.

\subsection{Some Theoretical Underpinnings}

According to the available body of literature the principal agent theory can be the best way to understand the relationship between citizen voice and public sector responses. The principal-agent theory assumes that the citizens are the principals in their relationship with public entities regardless of whether or not they actually live under representative forms of government (Griffin, Trevorrow \& Halpin, 2006). Furthermore, the approach postulates that citizens have uniform interests and goals as it is imported from the traditional two way market relationship of shareholder-managers or customers-service providers to explain the relations between citizens and public entities or officials. However, this theory's limitation is that it makes the wrong assumption that citizens have homogeneous needs and always act rationally. Unfortunately, empirical evidence have revealed that citizens do not always act rationally and have varied and often conflicting interests.

The new institutional theory is also useful in understanding how public entities emerge, operate and evolve in response to the demands of the environment. It helps in explaining how public entities interact with the citizenry as they deliver public goods and services. The theory suggests that public entities and officials are bound by laws, rules, values and procedures as they discharge their mandates. Citizens play a critical role in bringing public entities and officials to account by raising their voices against any wrongdoing. As principals, citizens put in place checks and balances to ensure that public entities and officials act according to set rules and norms. By exposing bad practices, citizens regulate the actions of public entities and officials.

The ladder of citizen participation model by Arnstein (1969) is also useful in understanding the different levels of citizen engagement. The model states that they are three main levels of citizen participation. At the lowest rung of the ladder, there is non-participation which is 
manifested by manipulation of the citizens by power holders. At the middle of the ladder there is tokenism characterised by placation, consultation and just informing the citizens. The highest point on the ladder is citizen power where citizens and the public entities partner each other. At this level there is active participation with citizens exercising great power and control over public entities.

The fiscal theory of price level re-developed by Cochrane (2005) helps in understanding why there is persistent resistance to successive council budgets as well as why the local authority's services have become inaccessible to citizens. The theory assumes that a public body's fiscal policy directly affects the price level for its services and thus for them to be accessible, levels of rates or taxation should be sustainable and affordable. It states that public entities should strive to provide services at the most optimum level in order for them to be accessible to the citizenry. In crafting its budget, a public entity's goal should thus be to attain price stability for its services. The model states that the higher the levels of rates or taxation, the less the citizens are able to honour their payments and vice versa. However, Buiter (2002) castigates the theory as fallacious and lacking specification and sense.

\subsection{Social Accountability in Zimbabwe}

Previous studies have suggested that the use of social accountability tools in Zimbabwe was introduced in the late 1990s by civil society organisations mainly to educate citizens about their rights and the level of services they should anticipate from public entities. Furthermore, it was introduced to monitor the actual performance of the various service providers and enlightening citizens about the mechanisms available to seek redress. According to Phute (2015) central government, civil society organisations, donor agencies and local authorities have attempted to implement the various social accountability tools in the past. A number of sectorial, fragmented and ad hoc social accountability interventions have been rolled out by the various stakeholders but have fizzled out amid bickering and accusations of a constrained democratic space from the demand side and counter accusations of ulterior motives from the supply side actors.

The new Constitution of Zimbabwe stipulates that citizens have a right to demand justifications and explanations from power holders. The preamble as well as chapters $2 ; 4$; 9; 13 and 14 creates many avenues for the promotion and implementation of social accountability. Furthermore, the enactment of the new Constitution in 2013 culminated in the creation of institutions that promote social accountability. However, these institutions still lack human, material and financial capacity to execute their specific mandates. The majority of these institutions have often been accused of being impotent and lacking. Empirical evidence has shown that marginalised members of society are still not aware of the provisions of the new supreme law and mainly rely on the interpretation of local political and bureaucratic elites who often sulk at social accountability due to the mistaken belief that it is meant to kick them out of office. This scepticism suggests that social accountability has not been well promoted in Zimbabwe.

On a positive note, the new government has shown commitment to implement reforms. The new dispensation has already taken concrete steps towards the implementation of the 
provisions of the new Constitution to promote social accountability. Examples of these practical steps include the requirement for political and bureaucratic elites to declare their assets; the restructuring of the anti-corruption body; the implementation of transparent budgeting and fiscal decentralisation. In order to entrench social accountability in the entire Zimbabwean system, stakeholders can learn from the best practices of social accountability from other parts of the globe.

\section{Social Accountability in Action: Some Empirical Evidence From Around the Globe}

\subsection{Information Dissemination}

Information dissemination can be a useful tool to address fiscal challenges faced by local authorities. This entails availing information about the budget process, the level of taxation and budget performance to the citizens. In a bid to test the assumption that local information dissemination of service delivery data results in greater responsiveness and accountability, Reinikka \& Svensson (2005) analysed the dissemination of school level funding information in Uganda. An information campaign was carried out to raise parents' awareness of block grants disbursed to schools. The campaign largely depended on newspapers for the dissemination of information and schools that had more access to newspapers experienced less leakages in grants and reduced diversion of funds than those that had less access to newspapers. While provision of information is vital, a number of empirical studies also found that information dissemination alone is not enough. In different studies Banerjee, Banerji, Duflo, Glennerster \& Khemani (2010); Lieberman, Posner \& Tsai (2014) found that dissemination of information about budget process to the citizens alone had no impact on responsiveness.

Available body of literature reveals that there is a positive relationship between information dissemination and improved fiscal management at local level. Local authorities need strong financial management systems in order to enhance transparency and accountability. Thus financial reporting needs to be strengthened with emphasis on disseminating timely and accurate accounting information to local citizens. Although there is no prescription on how or what kind of information should be disseminated by local authorities to citizens, the level of detail of the information should be enough to hold the local authorities accountable for the sources and uses of revenue. The evidence suggests that when citizens have access to accurate and timely information, they tend to cooperate with local authorities by honouring their dues on time and vice versa. Several studies carried out by the World Bank in Latin America concluded that there is a positive correlation between effective information dissemination and improved fiscal management at local level.

\subsection{Participatory Budgeting}

Participatory budgeting can also be an important tool to address the fiscal challenges faced by local authorities. According to Wampler (2007) participatory budgeting can be defined as a process which enables citizen involvement in deciding how public resources are to be distributed. It refers to a process whereby public entities allow their citizens to be involved at every stage of their budget formulation process. Budget formulation stages that citizens can 
participate in include: budget setting; budget implementation; budget monitoring and budget evaluation. Gonclaves (2014); Touchton \& Wampler (2013) studied numerous municipalities in Brazil over a period of twenty years. They compared social indicators in Brazilian municipalities with and without direct citizen participation in the budgeting process. Municipalities that employed participatory budgeting allocated a larger share of funding to sanitation and health services than those which did not thereby reducing infant mortality rates. They also found that participatory budgeting encouraged municipal authorities to focus on those services that meet the needs of under-represented citizens and improved citizen checks on budget performance. However, an increasing body of empirical research finds that social accountability approaches run the risk of collusion among concerned functionaries.

At local authority level, participatory budgeting helps to involve those left out of the traditional methods of public engagement such as minorities, low income residents, women, the physically disadvantaged, youths and others. Empirical studies in Brazilian municipalities reveal that participatory budgeting often results in more equitable public spending, greater governance transparency and accountability, increased levels of public participation by marginalised groups. Thus participatory budgeting allows citizens to deliberate and participate in the formulation of their local authority's budget. For example, in the Porto Alegre model of participatory budgeting citizens are given authority not only to demand services but also devise methods of financing them. The above evidence suggests that there is a positive relationship between participatory budgeting and improved fiscal management at local authority level.

\subsection{Community Budget Monitoring and Evaluation}

Community budget monitoring and evaluation helps to check whether actual expenditure matches budget allocations and ensures that funds are put to good use. It is a process whereby members of the public collect data about disbursements and performance measures over a period of time in order to give feedback to the concerned public entity (Sikhosana \& Nzewi, 2019). Citizens can do this by directly or indirectly monitoring implementation of projects and programmes. According to McNeil and Mumvuma (2006) budget monitoring ensures financial discipline and that budget promises are converted into tangible outcomes. Furthermore, it allows public entities to make modifications or take prompt remedial action where actual receipts or realities on the ground deviate from previously envisaged outcomes. In a field experiment in Uganda Bjorkman and Svensson (2009) worked with the civil society organisations to promote community monitoring of village health workers. The programme was designed to increase citizen voice, avoid elite capture and facilitate periodic dialogue between citizens and the village health workers. The community monitoring programme resulted in reduction in infant mortality by 33\%; 20\% increase in the use of outpatient services and overall improvement of health treatment practices. Fox (2015) argued that the positive results were a consequence of open dialogue and community assessment of service performance amid social rewards and sanctions.

As part of good practices in fiscal management, local authorities are expected to adhere to budget allocations and provisions. They should not deviate or divert funds from prioritised 
activities towards unbudgeted expenditure. Some local authorities in Zimbabwe have been accused of diverting public funds meant for capital projects or essential services to finance unbudgeted executive salaries and allowances. This practice breeds corruption which results in poor service delivery and thus applying community budget monitoring and evaluation allows citizens to monitor the council budget thereby minimising incidences of financial indiscipline.

\subsection{Public Expenditure Tracking}

According to Kanungo (2004) public expenditure tracking refers to a process whereby citizens are involved in tracing the flow of public resources meant for the provision of public goods or services from original source to destination. Sundet (2008) defines it as following the money to see whether it gets to the intended destination. It helps in doing away with bottlenecks, leakages, inefficiencies and corruption in the disbursement of public goods or funds right from the source to the end users. According to Joshi (2010), public expenditure tracking surveys have been used in many countries to highlight leakages and gaps in the disbursement of funds to the local level. Reinikka \& Svensson (2005) examined education expenditures in Uganda through public expenditure tracking surveys. The surveys indicated that only $13 \%$ of the actual expenditure meant for schools actually reached the intended destination. On making this information public, the amount of disbursements that reached the intended beneficiaries actually increased to $90 \%$ thus showing a significant improvement. However, as Hubbard (2007) noted, public expenditure tracking was not the only factor that contributed to the sharp decrease in leakage and perhaps not the most important.

Public expenditure tracking can be a useful to help local authorities improve their fiscal management positions. In Zimbabwe, local authorities receive a number of grants such as roads fund, inter-governmental fiscal transfers and other capital grants from central government. The best practices in fiscal management demand that these funds should be utilised in a transparent manner and that they must be accounted for to both central government and the local citizens. Local authorities can thus improve their fiscal management processes and practices by responding to citizen's questions on actual income and expenditure.

\subsection{Citizen Report Cards}

According to available body of literature, citizen report cards have been adopted from the private sector practice of consumer satisfaction surveys. Citizen groups carry out their own surveys on citizen level of satisfaction with the aim of exposing poor performance. By doing so, it is hoped that performance would eventually improve. Citizen report cards are usually individual opinion based and carried out at macro level (Joshi, 2010). In testing the effectiveness of citizen report cards as a mechanism for improving budget performance in Bangladesh, Ravindra (2004) found that they increased citizen mobilisation and awareness. However, other factors such as the presence of active and independent media and willing civil society organisations as well as the willingness of public officials to reform may also have contributed to the effectiveness of the tool. 
Thus citizen report cards can help local authorities receive valuable feedback on the budget before, during and after implementation. Local authorities can empower citizens to carry out their own surveys on the budget process, accuracy and impact on citizens' livelihoods. The feedback can in turn be used by local authorities to device methods of enhancing service delivery.

\section{Methodology}

Both qualitative and quantitative research methods were employed to understand perceptions on the budget process and trends in performance of successive council budgets. Stratified random sampling was used to select members of the public and local authority officials. A random sample of 200 people from the general population was selected to respond to a questionnaire on their views on the budgeting process; level of charges for the services provided; budget monitoring and budget performance. A sample of 10 employees stratified by department was selected to respond to a questionnaire to collect both quantitative and qualitative data on the budget process; budget setting; budget prioritisation and budget performance as well as the approval process. A review of relevant literature was done to explain underpinning theories as well as to better understand the concept of social accountability. Documentary review was also done to gather data on level of participation; budgeting process; budget performance; budget monitoring as well as the budget approval process.

\section{Results}

\subsection{Citizen Participation in Budgeting Process}

The results showed that the Goromonzi Rural District Council convened budget consultation meetings with the various stakeholders at sub district level. These budget consultation meetings were held at ward and cluster levels once every year. Participants indicated that ward budget consultation meetings were convened by the respective ward councillors and attended by all the people aged over 18 years residing in a particular ward. During these meetings councillors presented budget review reports detailing total revenue collected for the period and how it was utilised including the status of projects and programmes. Stakeholders were afforded the opportunity to seek clarification and give input before coming up with ward priority lists presented at cluster consultation meetings combining at least 8 wards. Cluster meetings were attended by relevant ward development committees; traditional leaders; churches; business people; informal traders; women and youth groups; and civil society from the demand side; and councillors, council officials and local bureaucrats on the supply side. During the meetings, ward priority reports were presented and debated before a consolidated budget review report was read by the finance committee chairperson and debated by all stakeholders in attendance. The results showed that $30 \%$ of the surveyed citizens had never participated in these budget consultation meetings. The rest $(70 \%)$ stated that they had participated either once $(27.5)$; twice $(15 \%)$; thrice $(13.5 \%)$; four times $(7.5 \%)$ or more than four times $(6.5 \%)$. 


\subsection{Local Authority's Budget Setting}

Participants indicated that Goromonzi Rural District Council's budget was set based on the Ministry of Local Government, Public Works and National Housing guidelines; the macroeconomic environment; the quantum and quality of public goods and services demanded as well as the cost of providing those public goods and services to the citizenry. Budget setting was dominated by the local authority's appointed and elected officials. Stakeholders were excluded in budget setting. The findings revealed that $60 \%$ of the respondents felt that the level of rates was too high and was beyond their reach. The rest of the participants $(40 \%)$ indicated that the charges were fair given the prevailing macroeconomic environment characterized by runaway inflation and liquidity challenges in the country.

\subsection{Citizen Involvement in Budget Prioritization}

Review of the local authority minutes showed that budget prioritization started from the ward level when ward development committees came up with their own priority lists for consideration by the finance committee of council. Documentary review also revealed that representatives of the various stakeholders attended finance committee meetings convened specifically for final prioritization and consolidation of the budget. During these meetings ward priorities were further prioritised and consolidated into a draft budget. The consolidated budget was then referred to full council for adoption before an advert was placed in the press for 30 days in terms of the Rural District Councils Act [Chapter 29:13]. Section 76 (3) of the said act provides that if thirty or more voters raise objections to any aspect of the proposed budget, council should reconsider the objections before finalisation.

\subsection{Citizen Satisfaction with the Local Authority's Budgeting Process}

Results of the study indicated that $55 \%$ of the surveyed citizens were satisfied with the local authority's budgeting process. A further $40 \%$ of the respondents expressed dissatisfaction with the council's budgeting process. The rest $(5 \%)$ of the surveyed citizens were not even aware of the local authority's budgeting process.

\subsection{Budget Monitoring}

A review of the local authority's documents revealed that the budget was monitored by the respective committees of council with the finance committee playing a leading role. The finance committee sat every month to consider financial statements and monitor budget implementation and performance. The local authority's minutes showed that other committees of council also monitored their respective budgets on a quarterly basis. Representatives of citizen groups and other stakeholders were not invited to those committee meetings as these were not open to members of the public in terms of the Rural District Councils Act [Chapter 29:13]. However, the said act provides that citizens had a right to attend full council meetings as observers. Documentary review indicated that the local authority invited the various stakeholders to full council meetings which received budget monitoring reports from the respective committees. The members of the public and other stakeholders had no voting powers but only attended as observers in terms of the statutes. 
5.6 Budget Performance

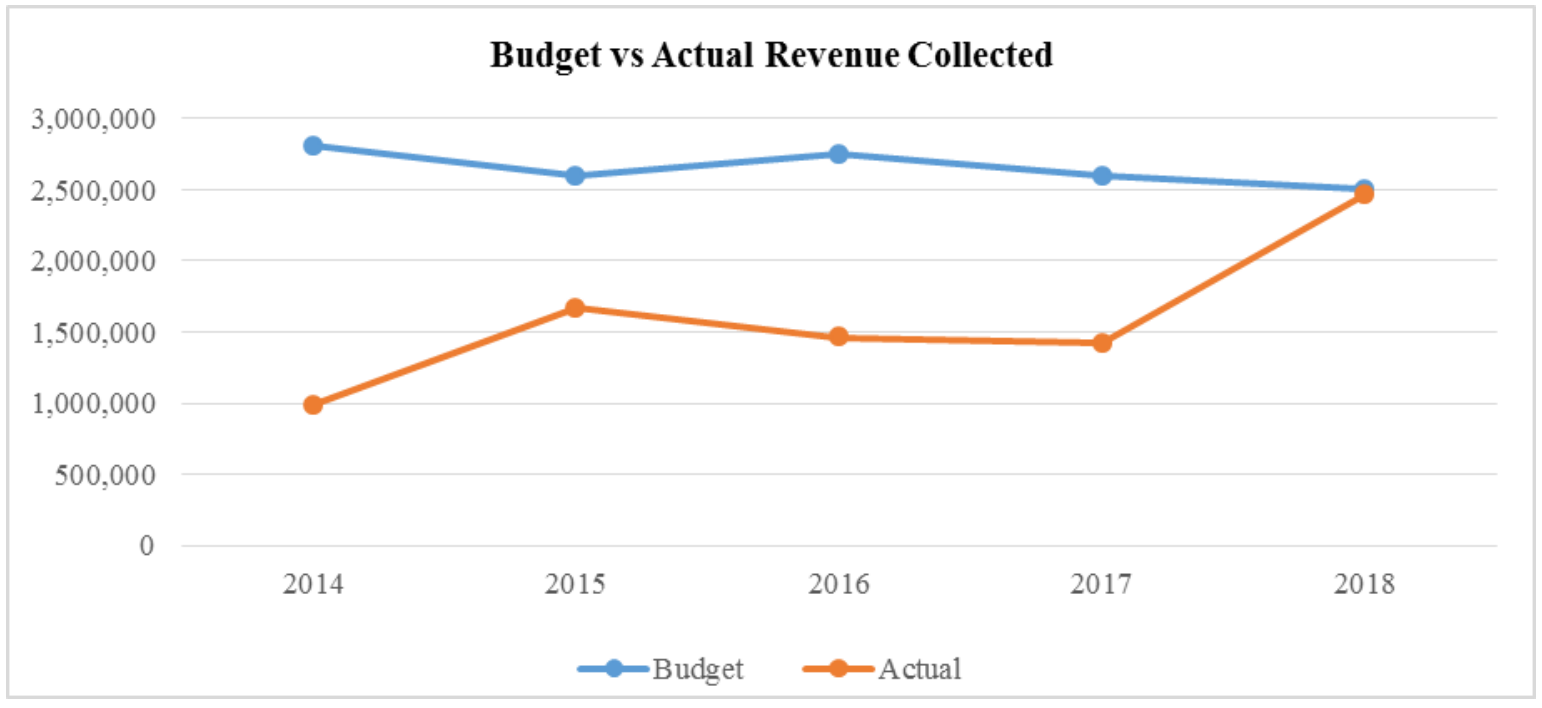

Figure 2. Budget Performance (2014-2018)

Source: Goromonzi rural district council financial records (2019)

Figure 2 shows that revenue collected by the local authority had always been lower than the budget for the period 2014 to 2018. The deficit in funding ranged from -1,821,046 in 2014 to $-38,663$ in 2018 . Generally there was an upward trend in revenue collection during the period 2014 to 2018 although there was a slight decline during the period 2015-2016. Participants indicated that the improvement was due to cooperation by the various stakeholders particularly the vendors, business people and mining operations following application of social accountability mechanisms. Documentary review showed that there was non-cooperation from the communal, A1 and A2 farmers as development levies performed badly. A debtor's analysis for the same period showed that the debtors figure had ballooned to unprecedented levels.

\subsection{Citizens'Views on Budget Approval Process}

Participants indicated that the budget was first ratified by full council before being forwarded to the Minister of Local Government, Public Works and National Housing for approval. Documentary review revealed that the minister had the power to vary or reject the proposed budget in the public interest. Participants responded that the approval process was too long and resulted in delays in the implementation of the budget. They felt that the budget should be implemented soon after ratification by full council rather than wait for ministerial approval. The majority of the surveyed residents indicated that the requirement for ministerial approval was unnecessary, while the rest $(40 \%)$ expressed the opinion that it was necessary to bring the local authority to account.

\section{Discussion and Recommendations}

The main findings of this study suggest that the use of social accountability mechanisms had a positive impact on the fiscal management challenges faced by Goromonzi Rural District 
Council. The positive perceptions and the high level of satisfaction with the local authority's budgeting process as well as the marked increase in revenue collection in 2018 were testament to the positive impact of social accountability initiatives. Thus the study results approved the hypothesis that the use of social accountability mechanisms may help address the fiscal management challenges facing local authorities by enhancing the relationship between citizens and power holders.

The adoption of mixed methods in the current study was useful to separate the different types of data and better appreciate the contradictions between qualitative and quantitative data gathered. It was possible to verify qualitative responses by comparing with quantitative data. The results indicated that mixed methods can achieve better results than other methods in the study of the impact of social accountability on the fiscal management challenges. The use of the questionnaire as the main data collection instrument was appropriate and convenient to gather both qualitative and quantitative data within the limited time and resources. The data collection technique allowed respondents to freely express themselves and answer truthfully to questions asked thereby eliminating biases. The questionnaire was most appropriate to gather data on public knowledge, perceptions and feelings as regards the impact of social accountability mechanisms. Literature review helped to define the concepts, explain underlying theories in social accountability as well as gather empirical data. Documentary review was useful to validate the claims made by respondents. The study was however limited due to the restricted movement of researcher owing to the government's coronavirus disease mandatory lock down which was in force during the study.

The results indicated that although the local authority has implemented some aspects of participatory budgeting as defined by the Wampler (2007), the application of social accountability mechanisms was still at its infancy. It can also be deduced from the results that the model of participatory budgeting practiced by Goromonzi Rural District Council differs from the Porto Alegre City one where the distinct citizen groups initiate the budgeting process and are heavily involved in all the stages of the budget cycle. The results were however consistent with those of other studies on participatory budgeting in Zimbabwean local authorities. For example, in a study of participatory budgeting in Kwekwe City, Marumahoko, Chigwata \& Nhede (2018) concluded that the model was dominated by council officials and councillors hence could hardly count as participatory. Although results show that citizens were consulted at village and ward levels, they were not fully involved in the actual budget costing and setting. There is need for the local authority to reconfigure its entire budgeting process in order to ensure that all the stakeholders are involved at every stage.

It can also be discerned from the results that Goromonzi Rural District Council's efforts to fully embrace participatory budgeting was constrained by the legal context in which it operated. Although Phute (2014) concluded that sections 13; 119; 141; 194; 298; 299; 300; and 309-314 of the Constitution of Zimbabwe already provide for citizen involvement in governance at all levels, the supreme law is yet to be fully implemented. It appears that the current configuration of the local authority's budgeting process was designed mainly to fulfil the requirements of legislation and central government guidelines rather than enhance citizen involvement. The results were consistent with the arguments put forward by Fox (2015) that 
the success of social accountability mechanisms is directly correlated with the environment in which they are implemented. There is need for central government to expedite the implementation of the new Constitution and realign relevant legislation in accordance with its provisions.

The results mean that although Goromonzi Rural District Council had not embraced all the aspects of participatory budgeting, its relationship with key stakeholders had significantly improved. These results are consistent with a number of studies from across the world that concluded that the use of social accountability tools can has a positive effect on the relationship between citizens and those that govern them. For example, in a study of social accountability and public service delivery in rural Africa Cold-Ravnkilde \& Friis-Hansen (2014) concluded that the relationship between Mutoko Rural District Council and its citizens had significantly improved after implementing participatory budgeting processes and information dissemination to promote mutual dialogue. However, there is in need for caution as community driven development programmes are often in danger of capture by the local elites for their own interests (Mansuri, 2013).

The study findings indicated that Goromonzi Rural District Council's revenue collection significantly improved in 2018 after successive years of citizen involvement in the budgeting process. These results confirm the main question of the study on whether the implementation of social accountability tools can have an effect on fiscal management challenges facing local authorities. By consulting its stakeholders, the local authority significantly improved its revenue collection and its fiscal management position. However, as Keefer \& Khemani (2012) suggested other factors such as the structure of incentives for both elected and appointed public officials could also have had an influence on responsiveness and improved service delivery. There is need for further research in order to establish whether the significant improvement in revenue collection by the local authority was solely a result of participatory budgeting or there were other factors at play.

Somewhat surprisingly, the significant increase in the local authority's revenue collection in 2018 was recorded despite the majority (60\%) of respondents feeling that the budget was set way above what they could afford. These results disapproved Cochrane's (2005) fiscal theory of price level which suggests that when levels of the local authority's taxes are too high, citizens respond by not honouring their payments. On the contrary, the high debtors' figure arising from the high default rate regarding communal, A1 and A2 farmers seems to substantiate Cochrane's theory of fiscal price level. Thus it can also be deduced from the main results that the high default rate may have been caused by the inability to pay rather than mere rejection of the local authority's budget. The results suggested that the local authority is yet to attain price stability for its public services and most may still be inaccessible to its citizens. The local authority should reconsider its costing and pricing models to ensure that its levels of taxes are sustainable and affordable. In a bid to curb its ballooning debtors' figure, the local authority should ponder negotiating for staggered payment arrangements with the relevant defaulters while working to achieve price stability.

The findings indicated that Goromonzi Rural District Council's efforts to improve its fiscal 
position are yet bear fruit as evidenced by the relatively high percentage of citizens who have never participated in its budget consultation meetings. Although the majority of the respondents indicated that they had participated in budget consultation meetings, the proportion of those who had never participated was still too high. Empirical evidence indicates that social accountability interventions demand that all citizens' views including those of minorities and underprivileged groups should be taken on board. Conversely, the results indicated that some people were still being excluded in contradiction with provisions of the Constitution. Section 264 (2) (d) provides that one of the objectives of devolution should be to recognise the right of communities to manage their own affairs and to further their development meaning no one must be excluded. There is need for the local authority to embark on an extensive capacity building programme aimed at educating all citizens within its area of jurisdiction on their rights to participate in local decision making. The programme should also target the local authority's appointed and elected officials to train them on the provisions of the Constitution and their obligation to promote the participation of all citizens in local decision making. However, empirical data has shown that the implementation of social accountability mechanisms can be expensive and requires significant amount of investment. There is also scope for further research to explore the costs and benefits of adopting social accountability mechanisms to both public entities and the citizens.

The involvement of all council committees in budget monitoring is evidence that the local authority is implementing transparency budgeting. This means that the policy makers who are the representatives of the grassroots are afforded the chance to scrutinise financial records and be able to seek clarification from the executive on behalf of the citizens. The committee based budget monitoring also ensures ownership and responsibility by the various committees of council which in itself leads to good fiscal management practices. The exclusion of citizen representatives from committee deliberations indicates that the local authority was also implementing the long route method. These results confirm the assertion that the long and short route methods are intertwined and complementary in demanding public accountability (Devarajan et al, 2014). However, they differ greatly to the results obtained in Brazilian cities where citizens are involved in the monitoring and evaluation of the budget. The local authority should review its fiscal management policies and practices in line with the best practices from other parts of the globe.

The majority of participants indicated that the requirement for ministerial approval of the budget infringed on their rights to participate in local decision making. This requirement is not consistent with section 264 (2) (a) of the Constitution which stipulates that powers of local governance should be given to the people to enhance their participation in the exercise of the powers of the state and in making decisions that affect them. Empirical evidence has shown that social accountability has been applied with a high degree of success under democratic systems such as Zimbabwe's. There is scope for further research to explore how social accountability mechanisms would fare under autocratic systems of government.

\subsection{Conclusion}

Fiscal management challenges have threatened the mere existence of local authorities 
worldwide particularly in Sub-Saharan Africa. Due to the alarming levels of fiscal mismanagement in these public entities social accountability has been adopted to promote participatory, inclusive and democratic local decision making in Zimbabwe. This paper has demonstrated that social accountability can be an effective tool to improve local authorities' fiscal management positions when implemented with a host of other traditional long route methods under an enabling environment. The enactment of the new Constitution and the emergence of the second republic under the new dispensation presented opportunities for the scaling up social accountability in Zimbabwe. The proposed amendment and realignment of relevant statutes as well as the implementation of devolution in line with the Constitution should therefore be expedited. However, the importance of traditional bureaucratic main accountability institutions such as parliamentary committees; anti-corruption bodies, ombudsman, auditor general and other independent bodies should not be diminished. Similarly, internal and external checks balances such as internal and external audits remain pivotal in augmenting transparency and accountability in fiscal management.

\section{References}

Agarwal, S., Heltberg, R., \& Diachok, M. (2009). Scaling Up Social Accountability in World Bank Operations. London: Institute of Development Studies.

Arnstein, S. R. (1969). A Ladder of Citizen Participation. Journal of the American Planning Association, 35(4), 216-224. https://dx.doi.org/10.80/01944366908977225

Banerjee, A., Banerji, R., Duflo, E., Glennerster, R., \& Khemani, S. (2010). Pitfalls of Participatory Programs: Evidence from Randomised Evaluation in Education in India. American Economic Journal: Economic Policy, 2(1), 1-30. https://doi.org/10.1257/pol.2.1.1

Barberis, P. (1998). The New Public Management and a New Accountability. Public Administration Journal, 76(3), 449-469. https://doi.org/10.1111/1467-9299.00111

Bardhi, A., \& Spahiu, B. (2015). Social Accountability and Child Rights Budget Analysis Manual: Using Government budgets to implement Children's Rights in Albania, Tirana: Institute of Contemporary Studies.

Bjorkman, M., \& Svensson, J. (2009). Power to the People: Evidence from a Randomised Field Experiment on Community Based Monitoring in Uganda. The Quarterly Journal of Economics, 124(2), 735-769. https://doi.org/10.1162/qjec.2019.124.2.735

Buiter, W. H. (2002). The Fallacy of the Fiscal Theory of the Price Level, Again, Bank of England Working Paper No. 141. https://doi.org/10.2139/ssrn.282189

Cochrane, J. H. (2005). Money as Stock. Journal of Monetary Economics, 52(3), 501-528. https://doi.org/10.1016/j.jmoneco.2004.07.004

Cold-Ravnkilde, S. M., \& Friis-Hansen, E. (2014). Social Accountability and Public Service Delivery in Rural Africa. http://dx.doi.org/10.13140-2.1.3270.5929

Devarajan, S., Khemani, S., \& Walton, M. (2014). Can Civil Society Overcome Government Failure in Africa? World Bank Research Observer, 29(1), 20-47. 
https://doi.org/10.1093/wbro/lkt008

Fox, J. (2015). Social Accountability: What Does the Evidence Really Say? Journal of World Development, 72, 346-361. https://doi.org/10.1016/j.worlddev.2015.03.011

Gonclaves, S. (2014). The Effects of Participatory Budgeting on Municipal Expenditures and Infant Mortality in Brazil. Journal of World Development, 53, 94-110. https://doi.org/10.1016/j.worlddev.2013.01.009

Griffin, D., Trevorrow, P., \& Halpin, E. (2006). Using SMS Texting to Encourage Democratic Participation by Youth Citizens: A Case Study of a Project in an English Local Authority. Electronic Journal of e-Government, 4(2), 63-70.

Hopwood, A. G., \& Thomkins, C. (1984). Accounting in the Public Sector. Oxford: Philip Alan.

Houtzager, P., \& Joshi, A. (2008). Introduction: Contours of a Research Project and Early Findings. IDS Bulletin, 38(6), 1-9. https://doi.org/10.1111/j.1759-5436.2007.tb00413.x

Hubbard, P. (2007). Putting the Power of Transparency in Context: Information's Role in Reducing Corruption in Uganda's Education Sector, Working Paper No.136. Washington D.C: Centre for Global Development. https://doi.org/10.2139/ssrn.1100131

Joshi, A. (2010). Service Delivery: Review of Impact and Effectiveness of Transparency and Accountability Initiatives. London: Institute of Development Studies. 1-17. https://doi.org/10.2139/ssrn.2188164

Kanungo, P. (2004). Public Expenditure Tracking Surveys-Application in Uganda, Tanzania, Ghana and Honduras. Empowerment Case Studies. Washington D.C: World Bank.

Keefer, P., \& Khemani, S. (2012). Do informed Citizens Receive More...Or Pay More? The Impact of Radio on the Government Distribution of Public Health Benefits. Washington D.C: World Bank. https://doi.org/10.1596/1813-9450-5952

Kohli, D. S. (2012). Manual on Social Accountability: Concepts \& Tools. New Delhi: Centre for Budget and Governance Accountability. Retrieved from

Lieberman, S. E, Posner, D. N., \& Tsai, L. L. (2014). Does Information Lead to More Active Citizenship? Evidence from an Education in Rural Kenya. Journal of World Development, 60(2013), 1-57. https://doi.org/10.1016/j.worlddev.2014.03.014

Malena, C., Forster, R., \& Singh, J. (2004). Social Accountability: An introduction to the Concept and Emerging Practice. World Bank Social Development Papers, Participation and Civic Engagement No. 76. Washington D.C: World Bank Group.

Mansuri, G. (2013). Localising Development: Does Participation Work? Washington D.C: World Bank Policy Research Report. https//doi.org/10.1596/978-0-8213-8256-1

Marumahoko, S., Chigwata, T. C., \& Nhede, N. T. (2018). Participatory Budgeting in the City of Kwekwe, Zimbabwe. African Journal of Public Affairs, 10(4), 196-211. 
McNeil, M., \& Mumvuma, T. (2006). Demanding Good Governance: A Stocktaking of Social Accountability Initiatives by Civil Society in Anglophone Africa. Washington DC: World Bank Papers.

Muchadenyika, D. (2017). Civil Society, Social Accountability and Service Delivery in Zimbabwe, Journal of Development Policy Review, 1-18. https://doi.org/10.1111.dpr.12242

Munyede, P., \& Mapuva, J. (2020). Exploring Public Procurement Reforms in Rural Authorities in Zimbabwe. Journal of Public Administration and Governance, 10(1), 1-16. https//doi.org/10.5296/jpag.v10i1.15156

Newell, P., \& Bellour, S. (2002). Mapping Accountability : Origins, Contexts and Implication for Development. Working Paper Series, 168. Brighton: Institute of Development Studies. [Online] Available: https://opendocs.ids.ac.uk/opendocs/handle/20.500.12413/3930.

Nigro F. A., \& Nigro, L. G. (1988). Modern Public Administration. Gloucester: Longman Higher Education.

Phute, T. (2014). Social Accountability and Citizen Engagement: Understanding Poor Service Delivery in the Zimbabwean Context. Harare: Pact Zimbabwe, 1-9.

Ravindra, A. (2004). An Assessment of the Impact of Bangalore Citizen Report Cards on the Performance of Public Agencies, Washington D.C: Operations Evaluation Department.

Reinikka, R., \& Svensson, J. (2005). Fighting Corruption to Improve Schooling: Evidence from a Newspaper Campaign in Uganda. Journal of the European Economic Association, 3(2), 1-7. https://doi.org//10.1162/jeea.2005.3.2-3.259

Ringold, D., Holla, D., Koziol, A., Srinivasan, M., \& Santhosh. (2012). Citizen and Delivery: Assessing the Use of Social Accountability Approaches in Human Development, Washington D.C: World Bank. https://doi.org/10.1596/978-0-8213-890-0

Shah, A. (2007). Performance Accountability and Combating Corruption. Washington D.C: The World Bank. https://doi.org/10.1596/978-0-8213-6941-8

Sikhosana, N., \& Nzewi, O. (2019). An Overview of Public Sector Budget Monitoring \& Evaluation Systems for Gender Equality: Lessons from Uganda and Rwanda. Journal of Reviews on Global Economics, 8, 477-489. https://doi.org/10.6000/1929-7092.2019.08.41

Sundet, G. (2008). Following the Money: Do Public Expenditure Tracking Surveys Matter? Bergen: U4 Anti-Corruption Resource Centre, Chr. Michelsen Institute.

Touchton, M., \& Wampler, B. (2013). Improving Social Well-Being through New Democratic $\begin{array}{lllll}\text { Institutions. } & \text { Comparative } \quad \text { Political } & \text { Studies, } & \text { 20(10), } & \text { 1-28 }\end{array}$ https://doi.org/10.1177/0010414013512601

UNDP. (2013). Reflections on Social Accountability: Catalysing Democratic Governance to Accelerate Progress towards the Millennium Development Goals, 1-134.

Visser, C. B., \& Erasmus, P. W. (2002).The Management of Public Finance: A Practical 
Guide. Oxford: Oxford University Press.

Wampler, B. (2007). A Guide to Participatory Budgeting. In A. Shah (Ed.), Participatory Budgeting (pp.21-36). Washington D.C: World Bank Public Sector and Accountability Series.

World Bank. (2003). World Development Report: Making Services Work for the Poor People-Overview (English), Washington D.C: World Bank Group.

ZIMSTAT. (2013). Zimbabwe National Census Report 2012.

\section{Copyright Disclaimer}

Copyright for this article is retained by the author(s), with first publication rights granted to the journal.

This is an open-access article distributed under the terms and conditions of the Creative Commons Attribution license (http://creativecommons.org/licenses/by/4.0/). 